Journal of Southeast Asian

\title{
Three Poems: The Dog at the Hospital; Bracken Ferns; Branta Canadensis
}

Pos L. Moua

University of California, Davis, pmoua6903@yahoo.com

Follow this and additional works at: https://docs.lib.purdue.edu/jsaaea

Part of the Bilingual, Multilingual, and Multicultural Education Commons, and the Literature in English, North America, Ethnic and Cultural Minority Commons

\section{Recommended Citation}

Moua, Pos L. (2019) "Three Poems: The Dog at the Hospital; Bracken Ferns; Branta Canadensis," Journal of Southeast Asian American Education and Advancement. Vol. 14 : Iss. 1, Article 12.

DOI: $10.7771 / 2153-8999.1194$

Available at: https://docs.lib.purdue.edu/jsaaea/vol14/iss1/12

This document has been made available through Purdue e-Pubs, a service of the Purdue University Libraries. Please contact epubs@purdue.edu for additional information.

This is an Open Access journal. This means that it uses a funding model that does not charge readers or their institutions for access. Readers may freely read, download, copy, distribute, print, search, or link to the full texts of articles. This journal is covered under the CC BY-NC-ND license. 


\section{Three Poems: The Dog at the Hospital; Bracken Ferns; Branta Canadensis}

\section{Cover Page Footnote}

Special acknowledgments go the following persons for making these poems come alive: Mao Lee, Se Lee, Tong Ying Vang, Xee Ha, Blia Yee Lee, and Se Lor. Their love of exploration and adventure around the national forests pave the foundation for these poems. 


\title{
USAAEA Journal of Southeast Asian American
Education and Advancement
}

Vol. 14 Iss. 1 (2019)

WwW.JSAAEA.org

\section{Creative and Literary Works}

\author{
Three Poems
}

\author{
Pos L. Moua \\ Merced College
}

\section{The Dog at the Hospital}

I read that a very loyal, unnamed dog would lay Down on a raggedy but beloved towel outside

The hospital in Brazil to wait five months long For its owner to return as he had often done.

As it lay waiting at the hospital door, people Would come and go, as they enter the door,

The dog, in its drooping, mellow somberness, Would stare at them and graciously moved out

Of the way so they could enter the hospital. It would leave that place by the entrance

Of that house of someone's hope only to find Food and again return to the same spot to wait.

Once, the dog kennel took it two miles away And imprisoned it for its daily obstruction,

But it eventually escaped and returned to wait, Day after day, for time is neither cruel nor kind

To it, whose heart must linger like an old man

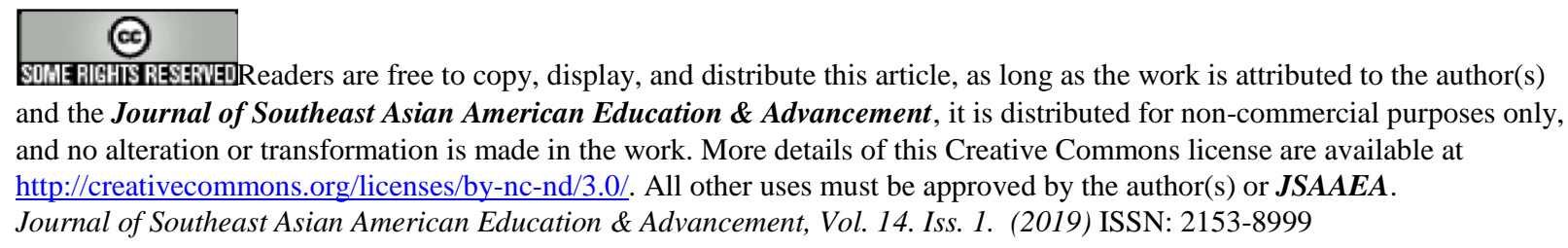


Trying to warm himself by a slow quivering flame.

Does it wait to enter the door of nirvana-heaven The way its owner and truthful friend who had

Been stabbed to death, or does it wait for love? I do not think it's waiting for its owner to return:

It is waiting to follow its owner: for what else is Purpose when love isn't daily engendered

Through the usual voice, the usual path to The market or to the lone, usual dumpster and

For what else must one live when life is fleeting Like a long stumbling flow of the river towards

That evening horizon, and the familiarity of love Isn't scented in the air like the scent you daily

Carry to me by the couch and along the hallway, All the way to and from San Francisco Bay, my love.

\section{Bracken Ferns}

"Nip the tips of these with your fingernails, only these young fiddleheads," such agile demonstration, how your fingers smile and fiddle through the patch of ferns like a hungry doe.

As I follow you up the slope, I practice collecting those eagle's clenched talons those elegant fronds unfurling the way you curl cozily like a spiraling snail-shell, translucent on the bed I made.

Each clasp of the fern head, at each horseshoe bend, almost closing, is a babe's clenched fist I yearn to kiss and let cuddle over my cheeks, and in the sunlight by the shades

of the oaks, the odiferous pines incant 
spirits of the Sierra and suns closer

to your tender, leavened voice-

your nape and cheeks brighten

and I look uphill at you and the sky blues.

\section{Branta Canadensis}

"It was a little after the evening and the dark was just about to set, the horizon hazed in gold;

I said to myself, 'I'll wait in these trees to see if any of them fly low."

A little later the hunter knocked on my door; cheerfulness in his greeting, he asked for a bag and told of his last-minute hunting excitement, as if he were forgoing safety, desire, and freedom.

That night my wife and I gutted a magnificent mother whose wingspan outstretched mine over the green lawnsuch angelic feathers from Alaska, from cold Canada, through the freezing.

With it fell another white goose along with two buffleheads and two fist-size teals, their green wings iridescent and downy; even lifeless, they're reminiscent of life like the surface of a pond swaying to breezes.

We tried to pluck the long feathers and their soft simple downs, almost like cushioning clouds of wintry sky, pillows for the souls to rest, attachments to earth and its diffusive spectrum.

In my heart, I imagine the fall, the shots, and the last cry, farewell to its love, whose wings flapped along side hers just before the burst of pallets exploding from within the hidden bushes,

pallets scattering like stringing 
strings of arrows, death, and dreadful shrieks against life and long travel - an ending to when there was a beginning since its fledgling days.

I imagine my love walking beside me shot and fell beside me, blood spewing, oh, heaven, all beauty, memories, yearnings, faded, sank into the abyss of silence over wind-swept tules and mud:

My mind flashed back to the night when machine gun let bullets flared, streaking lines of sorrow like blood pens drawn across the pitch of night and those screams haunt me long after.

As we peeled off skin along with fat and its elegant plumage from its long neck, now stiff to the bones, bruised and blood-clogged on the side to its thigh, a deep gushing wound.

I snipped the legs and wings, uttered a silent prayer and heard its spirit whispered, "Oh love, was this a journey to slough pastures of San Luis and then to the equatorial warmth of Mexico and the dancing sea?"

\section{About the Author}



Pos L. Moua, lives in Merced, California, with his wife and five children. He is a language arts teacher who has taught Hmong and English at Merced High School and Merced College for over 20 years. He is a member of Hmong American Writers' Circle (HAWC). His first chapbook, Where The Torches are Burning (Swan Scythe Press, 2001) gives "an account of love and family and identity in the poet's new land." His poems have appeared in the anthologies Tilting the Continent: Southeast Asian American Writing (New Rivers Press, 2000) and How Do I Begin?: A Hmong American Literary Anthology (Heyday Books, 2011). His latest collection of poems, Karst Mountains Will Bloom (Blue Oak Press, 2019) is praised as "a landmark achievement: ascendant, transcendent, visionary." 


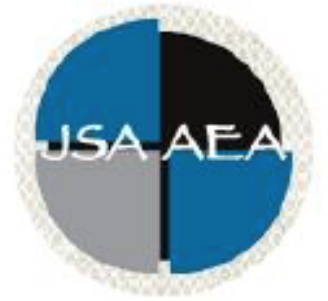

Vol.14 Iss.1 (2019)

\title{
Journal of Southeast Asian American Education and Advancement
}

\author{
WwW.JSAAEA.org
}

\section{Editor}

Dr. Wayne E. Wright

Purdue University

Associate Editors

Dr. Chhany Sak-Humphry

University of Hawaii at Manoa

Dr. Phitsamay Sychitkokhong Uy

University of Massachusetts, Lowell

\author{
Book Review Editor \\ Dr. Vichet Chhuon \\ University of Minnesota \\ Creative Works Editor \\ Bryan Thao Worra \\ Lao Assistance Center \\ Journal Manager \\ Fang Gao \\ Purdue University
}

\section{Editorial Review Board}

\author{
Dr. Steve Arounsack \\ California State University, Stanislaus \\ Dr. Sovicheth Boun \\ Salem State University \\ Dr. Virak Chan \\ Purdue University \\ Dr. Loan Dao \\ University of Massachusetts Boston
}

Dr. Carl L. Bankston III

Tulane University

Dr. Phala Chea

Lowell Public Schools

Dr. George Chigas

University of Massachusetts, Lowell

Dr. Hien Duc Do

San Jose State University 
Dr. Changming Duan

University of Missouri-Kansas City

Dr. Sothy Eng

Lehigh University

Dr. Vincent K. Her

University of Wisconsin, Eau Claire

Dr. Peter Nien-Chu Kiang

University of Massachusetts, Boston

Dr. Kevin K. Kumashiro

University of Illinois, Chicago

Dr. Ha Lam

Eastern Mennonite University

Dr. Jonathan H. X. Lee

San Francisco State University

Dr. Monirith Ly

Royal University of Phnom Penh

Dr. Bic Ngo

University of Minnesota

Dr. Leakhena Nou

California State University, Long Beach

Dr. Mark Pfeifer

SUNY Institute of Technology

Dr. Loan T. Phan

University of New Hampshire

Dr. Karen Quintiliani

California State University, Long Beach

Dr. Angela Reyes

Hunter College

The City University of New York

Dr. Fay Shin

California State University, Long Beach

Dr. Christine Su

College of San Mateo

Dr. Alisia Tran

Arizona State University

Dr. Khatharya Um

University of California, Berkeley

Dr. Kim Tran

University of California, Los Angeles,

Glendale Community College

Dr. Soua Xiong

California State University, Fresno

Dr. Zha Blong Xiong

University of Minnesota
Dr. Sophal Ear

Occidental College

Dr. Jeremy Hein

University of Wisconsin, Eau Claire

Dr. Nancy H. Hornberger

University of Pennsylvania

Dr. Peter Tan Keo

New York University

Dr. Yvonne Kwan

San Jose State University

Dr. Ravy Lao

California State University, Los Angeles

Dr. Stacey Lee

University of Wisconsin, Madison

Dr. Sue Needham

California State University, Dominguez Hills

Dr. Max Niedzwiecki

Daylight Consulting Group

Dr. Clara Park

California State University, Northridge

Dr. Giang Pham

University of Massachusetts Amherst

Dr. Malaphone Phommasa

University of Clifornia Santa Barbara

Dr. Kalyani Rai

University of Wisconsin-Milwaukee

Dr. Cathy J. Schlund-Vials

University of Connecticut, Storrs

Dr. Nancy J. Smith-Hefner

Boston University

Dr. Yer J. Thao

Portland State University

Dr. Monica M. Trieu

Purdue University

Dr. Silvy Un

Saint Paul Public Schools

Dr. Linda Trinh Vo

University of California, Irvine

Dr. Molly Wiebie

The University of Texas at Austin

Dr. Yang Sao Xiong

The University of Wisconsin-Madison 


\section{Doctoral Student Editorial Review Board}

Diana Chandara

University of Minnesota

Bao Diep

University of Minnesota

Nielsen Hul

Cornell University

Vanessa Na

University of California, San Diego

Hoa Nha Nguyen

Boston College

Linda Marie Pheng

University of Wisconsin-Madison

Mai Vang

University of Massachusetts Boston

Thong Vang

University of Minnesota

\author{
Linh Dang \\ University of Rochester \\ Annie BichLoan Duong \\ San Joaquin County Office of Education \\ Dung Minh Mao \\ University of Minnesota \\ Thien-Huong Ninh \\ University of Southern California \\ Khoi Nguyen \\ George Mason University \\ Krissyvan Truong \\ Claremont Graduate University \\ Melissa Vang \\ San Diego State University
}

